\title{
IMPROVING SPEAKING SKILL THROUGH PRESENTATION TASK AT THE FIRST YEAR STUDENTS OF PALM OIL POLYTECHNIC CITRA WIDYA EDUKASI - BEKASI
}

\author{
Abdulloh, M.Pd. \\ Lecturer of STIBA -IEC Bekasi \\ abdullahgraha@yahoo.com
}

\begin{abstract}
This paper aims at presenting the general outline of designing oral presentations task in speaking class for college students. The presentation task is as one of varied teaching techniques in teaching speaking skill in college environment especially for students of Palm Oil Polytechnic - Citra Widya Edukasi in Bekasi, in their English I and II subjects. There are two stages in this teaching design in one session of $3 \times 50$ minutes. The first half of the session used for speaking practice using the module provided and the second half used for presentation task. In presentation session they gather in group for preparing the topic of presentation related with their subjects or major (Management of Logistic and Palm Oil Processing of Harvest), still in group then they work together to finish the paper and power points. Guidance of presentation is given, let them rehearse or practice at home to be moderator, presenter, speaker or other roles. In class they rehearse their presentation in group consists of five to seven students three to four times in front of different goup before the real the whole class presentation begun. This study shows that the presentation task done in group by students genereates, accelerates and empowers studens to speak english confidently. This study also has many implication that lecturers may not neglect and underestimate students' capability. Lecturers should empower and give much oportunity to give presentation as their task. And lecturers should motivate, monitor, and facilitate them to be independent and motivated learners in English subject and other subjects in general.
\end{abstract}

Keywords: speaking skill, presentation task, English I and II, rehearse, independent and motivated learners.

\section{A. INTRODUCTION}

\section{Background.}

In global era speaking skill is becoming a more and more important for graduate students who will enter the most strategic and high managerial demands of job especially careers require speaking skill. Someone who has a 
good speaking skill will be more confident in speaking or to be the speaker. The company will select the candidate of employee with excellent skills, speaking or communication skills. Through practice, people can speak actively and effectively, that's why speaking skill becomes the one of main requirements of job entry.

Beside speaking, university students require more skill than the speaking skill, that is presentation skill for their career demand as mentioned above. According to ESP programme, to qualify for a Bachelor's degree, together with other skills, a student should be able to communicate in English in the world of work, that includes the ability to prepare public presentations on a wide range of professional topics, using relevant means of verbal communication and adequate forms of discussion and debate (Tarnopolskyy 2007).

Ideally high school graduates or first year college students have good basic speaking to prepare their further study in college. And logically students speaking skill is also already good when they enter higher study in college because they have learned it from very begginning of their schools; elementary, junior high school, senior high school, and even from english schools taken after their school hours. The fact found in some English classes is quite different with the ideal condition should be. The classes the writer observed show that mostly students with less capability of speaking skill. Simple interviewes were done in class and some other supported data to be analyzed as follows : less opportunity to practice in class before, demography of students that spreads from small cities or regions from Sabang to Merauke (see appendix 1).

The data collected from observation found that only few students come from big cities like Bekasi, Bogor and Jakarta. Things to be considered are original regions where they are from, parents educational backgrounds , ethnics, and regional languages. The regional languages also influence much of their speaking skill. In general their capability is relatively different from the same students who come from big cities. Besides some data collected above the writer also summarizes some other fact findings or factors that influence the bad speaking skills of first year of college students are: 
- Teachers, students, the ministry or the policy makers tend to focus on how to pass National Exams (NE). They tried hard with all efforts to pass the written test of national exam.

- Because of NE target, most students join extra course hours of subjects tested in NE outside after the school ours not certain skill such as speaking.

- Most English teachers give less opportunity to students to practice speaking or less exposure of english in class.

- Few English teachers apply some good teaching techniques after their daily teaching. They only cover the unit not the speaking skill.

- Large size of the class that consists of 30 to 40 even 50 students, commonly in state or public schools. It causes crowded and inconducive situation to learn.

From the problem identifications above, the writer tries one of the solutions to solve by presenting and discussing the outline and design of English program or syllabus of speaking skill in Palm Oil Polytechnic Citra Widya Edukasi, in Bekasi for two semesters, English I and II. Each of English program has two primary objectives: the first is to actively develop students' ability to communicate in a socially appropriate manner (general speaking skill practice). Secondly, there is a determined effort to build learners' confidence to speak in front of public and it is as one of the tasks during one semester, that is presentation skill (presenation task).The design of the program aims at two main target of speaking skill: general speaking practice and presentation skill. Both activities of speaking will give the students much more opportunity to practice speaking or conversation, and it is believed that it will generate, accelerate, and promote students speaking skill. Introducing and obligating students to deliver the presentations is also an effective means to motivating them to communicate in the target language.

\section{The Objective}

The objectives of this paper are to present the outline program and its implementation of general speaking skill, general speaking practice, spoken presentation skill, and the presentation task in college classes. This paper also 
provides complete steps of teaching presentation, and it also will show the effectiveness of presentation task as one of the teaching techniques in English classes for the college and as one of the considerations for lecturers to apply it.

\section{Theoritical Framework}

\subsection{Spoken Presentations}

Speaking is the mode of communication most often used to express opinions, make agreement, disagreement, arguments, request, offer and ask for help, offer and give explanations, ask and give direction, transmit and receive information, and make impressions upon others, etc.Communicating, contacting and, thus, connecting with colleagues and business partners is a crucial and an essential skill in career development. Graduates need to speak well in their personal and daily lives, future business setting, workplaces, social interactions. They will have business and some important formal meetings, lobbying, negotiating to attend, presentations to make, discussions and arguments to participate in, people, group of people to work and cooperate with. If basic instructions, a chance, and opportunities to practice speaking are available, graduates will fulfill the availabe position. As Halliday (1978) explains, "communication creates, maintains and modifies social reality through the exchange of meanings and understandings in the process of communication". It is a dynamic, interactive process that involves the effective transmission of facts, ideas, thoughts, feelings and values. It is tailored according to the needs of specific professions and allows students to present the acquired academic knowledge in both academic and professional environment.

There is also relationship between business's affairs and presentation skill with the effective communicators according to some writers. According to Murphy \& Hildebrandt (1990) "knowing the content of the functional areas of business is important, but to give life to those ideas - in meetings or in solo presentations - demands an effective oral presentation." The success largely depends on judging all the specifics of the situation and responding to those properly, as well as the impression one gives as a person. In order to be 
effective communicators, innovators, critical thinkers and problem solvers today's students "enhance their skills and capacities by improving their means of linking their skills and capacities to the world market" (Reich, 1991).

King also relates students presentation skill with other skill such as communication and the leadership. Students' spoken presentations are a common part of many courses at colleges and universities as they are one of the ways to improve learning of course material. They represent an opportunity for developing real-world communications as well as leadership skills (King, 2002).

\subsection{Speaking Skill or Spoken Communication Skills}

In General, language skills usually divided into two types; receptive skills and productive skills. Receptive skills is a term used for reading and listening, while productive skills is a term used for speaking and writing ( Harmer,2007).

Sladana Živkovic called speaking skill as Spoken Communication Skills, and both are the same terminology and meaning. As one the four language skills, speaking skill or spoken communication skill has been broadly and widely discussed by many linguists and educators since the beginning study of language learning. Sladana Živkovic quotes Hedge and Driscoll in his journal as follows:

Today's global society needs young people who are flexible, active innovative and creative in problem solving and decision making, who can communicate effectively and work collaboratively. This rapidly changing world needs young people to develop their potential as individuals in order to be prepared for the unique demands of the 21 st century world.The ability to communicate is important in order to be able to operate effectively in the real world (Hedge, 2000).

In the present era of globalization employability skills include, among all, communi- cation and presentation, planning, creative thinking, problem solving critical thinking, active and reflective application of knowledge (Driscoll,2000). The ability to communicate is the most important goal that language teaching 
aims to reach. It is to be able to operate effective-ly in the real world (Hedge, 2000).

Hedge and Driscoll insist young people or college students to master the communica-tion skills (spoken communication skill) strongly to face global's need and the unique demands of the 21st century. Based on all experts's statements above, the writer is trying to contribute the solution of that problem from a very little effort that is done in the classroom is by designing the program. The writer designs and modifies the program or syllabus of English I and II into two primary objectives as mentioned above: the first is to actively develop students' ability to communicate in a socially appropriate manner. Here is the first primary objective that is formulated into some steps of speaking skill practice :

- Design the syllabus emphasizes on speaking skill practice

- Select the material focuses on speaking task (hand out taken from Interchange 3rd ed. By Jack. C Richard with Jonathan Hull and Susan Proctor) and arranged into modul English I

- Apply Communicative Language Teaching in class by empowering students to practice speaking in pairs or in group.

- Let them perform the speaking practice based on the module or modify with the real situation.

Secondly, there is a determined effort to build learners' confidence to speak in front of public and it is as one of the tasks during one semester, that is presentation task. The session consists of $3 \times 50$ minutes. The first half of the session is done for first primary objective activities above, and the other half is used to present the second primary objectives, that is presentation task. The second steps are as follows :

- Divide the class into group, a group of presentation task.

- Apply the Collaborative and Cooperative Language Learning principles.

- Provide the students topic discussion related with their majors for their presentation task. The two majors are : Management of Logistic of Palm Oil Company and Processing Technology of Palm Oil Harvest.

or find out the topic of presentation themselves. 
- Ask the students to find out the topic by reading the books, magazines, newspapers, journal, or browse them from the internet.

- Write the topic in the organisation or structure of semi scientific short paper, started from the tittle, preface, table of content, chapter I, Introduction, background, chapter II : content or discussion, chapter III: Closing, summary, suggestion, References.

- Complete it with chart, graphs, pictures, audio, and videos if ossible.

- $\quad$ Prepare the presentation in power point.

- Rehearse the presentation at home or in class and perform it in small group before standing up in front of the whole class.

- Start the presentation after first primary objective activity is done or after speaking skill practice.

\subsection{Why Presentation}

Here are the reasons why we should choose presentation for students' speaking practice. The first four points are proposed by Diarmuid Mac Anthony, Gerardine in Mc Crohana Pedagogical Justification for Teaching Presentation:

a. The conversation classes delivered traditionally conversation/oral communication. Classes have focused on functional situations such as shopping, going to a restaurant, buying tickets etc.They added that students have been repeatedly exposed to such activities and by the time they reach university level have become bored and unmotivated by such constant repetition. This was one of the main reasons behind the decision to teach presentation skills in communicative English classes.

b. The presentation is a very useful tool in the improvement of an individual student's speaking skills. The students must speak in front of a group of people confidently. This requires practice, and an ability to express oneself verbally in a clear and concise manner, and it is often neglected by most students in colleges.

c. Expressing oneself clearly and fluently will greatly help in a student's development as an English speaker. 
d. The presentation can help to strengthen a student's pronunciation abilities. Not only will repeated practicing help improve a student's skills in this area, but also the scrutiny that presenting in front of a group allows will be of great benefit.

In addition, John Wilson in his Proceedings of classic 2014 continued to mention the benefit of presentation such as:

e. Using oral presentations allowed their students to interact and participate more in the classroom, which increased their students' interest in learning English, Girard, Pinar and Trapp (2011).

f. Oral presentations can also benefit students by helping them to bridge the gap between language study and language use (King, 2002).

g. Using oral presentations in the classroom is that they are student-centered.

h. Presentations are one of the few times in the language classroom that the students themselves have direct control of both the content and the flow of the classroom (Apple \& Kikuchi, 2007).

i. Benefit of oral presentations is that they require the use of all four language skills; writing, reading, speaking, and listening (King, 2002). Students are required to use their reading and writing skills to research and write their presentations. Presenting in front of the class requires students to use spoken English.

j. Oral presentations provide a more authentic way of practicing English than simple speaking drills.

k. Another benefit of oral presentations is that they can help provide students with additional motivation to study English (Hovane, 2009). This is because oral presentations do more than just give students an opportunity to practice language skills; they also give students an opportunity to teach something to their peers.

1. Researchers have shown that participating in presentations can be beneficial for students' future employment (Živković, 2014). 
There are still many reasons why presentation should be given to university or college students. The potential benefits of students' spoken presentations include (Girard et al, 2011):

- greater class interaction and participation,

- increased interest in learning,

- new perspectives not covered otherwise, and

- improvement in communication and presentation skills.

Students can gain knowledge not only from the research they and other students perform, but also by observing the other presenters' strengths and weaknesses to develop better communication and presentation skills" (Girard et al, 2011).

Spoken presentations represent an opportunity for developing realworld communica- tions as well as leadership skills (King, 2002). Among the many advantages of designing spoken presentations for students are (King, 2002):

- bridging the gap between language study and language use;

- using the four language skills in a naturally integrated way;

- helping students to collect, inquire, organize and construct information;

- enhancing team work;

- helping students become active and autonomous learners.

- to develop learners' confidence that they can achieve communicative goals,

\subsection{Presentation}

Presentation defines as a means of communication that can be adapted to various speaking situation, such as talking to a group, addressing a meeting or briefing a team. It can broad term that encompasses other speaking engagement such as making speech at a wedding, or getting a point across in video conference.

In journal "Teaching Students How to Master Spoken Presentation Skills ", Sladana Živkovic relates the discussion of presentation with communication lesson as follows: Communication for professional purposes occupies a significant part of language teaching classes. They should be designed to meet 
the job-specific needs of students (Hutchinson \& Waters, 1987; Dudley-Evans \& St. John, 1998), and allow them to present the acquired academic knowledge in the professional environment. Students need a lot of opportunity to practice language in situations which encourage them to communicate their needs, ideas and opinions.Communication skills are required by students (future specialists) whether they are expected to give presentations.

\subsection{Presentation Problem}

At the beginning of speaking class and presentation class, students are shy, less confident, afraid of making mistakes, word mispronuncing, and etc. They rely that they are lack of practice in their speaking in their previous study. Now, when the English I starts, they have problem of speaking or communication. The students' problem mentioned above is caused by the students's less opportunity to practice speaking and the solution for it is to give more opportunity in practicing their speaking skill in either speaking skill activity or presentation task activity. Since the presentation skills require higher speaking level, it becomes more serious problem of college students especially for everyone who have lower level.

The following information reveals what problem is in the presentation. There are two main factors why people have problem of public speaking or presentation , they are:

1) Internal factor means a factor that comes from the internal side of the speaker or people. In other terminology it can be said that it deals with the phsychological feeling such as: feeling of fear, anxiety, worried, shy, nervous, not confident and etc.

2) External factor means factor that comes from outside the phsychological feeling such

as ; knowledge of topic or subject they want to speak, knowledge of sentences structure the speakers should choose, choosing the apropriate words/diction they use, lack of reading, vocabulary, preparation, practice in the real situation. problem arise when There is a big difference between being nervous before speaking and feeling terrified. A certain amount of 
anxiety and tension before addressing a group is natural and even energising. What you need to do to succeed is to turn the experience around and focus on the positive implications of giving a presentation, rather than on the negative ones.

Many students feel that one of the major problems with oral communication classes is that they do not provide them with adequate opportunities to use English to communicate with others in the classroom (Ferris \& Tagg, 1996). Ferris, D., \& Tagg, T. (1996). Academic listening/ speaking tasks for ESL students: Problems, suggestions, and implications. TESOL Quarterly, 30(2), 297-320.

The main reason why so many people shy away from speaking in public is fear; the fear of going blank or forgetting what one had planned to say, the fear of sounding stupid or of boring the audience to death. Quite often, the anxiety provoking thought is that your name, career or reputation is at stake.

\subsection{Presentation Skill}

A presentation is described as 'a speech or talk in which a new product, idea, or piece of work is shown and explained to an audience (www. oxforddictionaries.com)' Presentation skills are 'the set of techniques and skills required to successfully present oral information to others' (www.collinsdictionary.com ).

Different books or references will be different discussion of the presentation. The writer tried to summarize from some sources. The presentation classified into 5 main steps:

1) The Preparation of the Presentation

2) Plan the Structure of Presentation

3) Preparation the Presentation Slide

4) Rehearse The Presentation

5) Delivering the Presentation 


\subsection{The Preparation of the Presentation}

The following stages help the beginners much to build and develop their presentation skills as their first preparation. A good preparation will determine the success of presenta-tion. Many students fail in presentation because they neglect the basic preparations. V.Tkachenko suggests 5 clues of question words that will lead them to start the preparation of the presentation; "why, who, where, how long, and what should I say"

1) Why am I making this presentation? Do I need to inform, to persuade, to train or to

sell? The objective of your presentation should be clear in your mind.

2) Who am I making this presentation to?

You should know who your audience is. How many people? Are they experts or non-experts? How much do they know already and what will they expect from you?

3) Where am I making this presentation?

You should know the venue. Will it be a small meeting-room or a large conference hall? What facilities and equipment are available? What are the seating arrangements?

4) How long will this presentation be?

You should know how much time you have.

5) What should I say? You should think about the content.

(V.Tkachenko:2014)

\subsection{Plan the Structure of Presentation}

These skills cover a variety of areas such as the structure of the presentation, the design of the slides, the tone of the voice, the body language, etc. Presentations skills are very useful in many aspects of work and life.Most presentations are organised in three parts, followed by questions (Tkachenko : 2014) : 


\begin{tabular}{|l|l|}
\hline -Short introduction & - welcome your audience \\
& - (introduce yourself) \\
& - introduce your subject \\
& - outline the structure of your presentation \\
& - tell the length of your presentation \\
& - explain the rules for questions \\
\hline -Body of presentation & - present the subject itself \\
\hline -Short conclusions & - summarise your presentation \\
& - thank your audience \\
& - invite questions \\
\hline
\end{tabular}

The Skills Team, University of Hull divides differently the structure of presentation with the structure above, but when we read carefully they are almost same. The structure is :

1) The beginning section is where you hook them. Start with the general picture then

explain the specific problem and how by listening to your presentation you can solve it

for them.

2) The middle section should contain the main detail of your presentation, and can be

organised in a number of ways (the two best are showcased below).

3) Finally your end section should summarise the presentation and lead the audience to

the next step.

\subsection{Micro and Macro Skills of Presentation.}

Sladana Zivkovic classifies kind of presentation skills into two: micro skills and macro skills. Here are the complete elaboration of those skills. It is important for the teacher of an oral presentation class to spend time introducing students to both the macro and micro skills needed to give oral presentations. If this is not done then the students will not have confidence in their ability to 
present and "will feel that the teacher has just dumped them into the sea to struggle for survival (King, 2002, p. 406)."

The micro level skills taught in this course included things like genre specific language items, such as vocabulary and grammar, that students would need to be successful in their oral presentations. These items are important to the students for two reasons. First of all, they allow students to be successful when they are presenting in the class. Secondly, the language and grammar students learn in the course of giving a presentation will be useful for them in other situations that involve spoken English (Thornbury, 2005). Because of this, the teaching of these genre specific micro-skills is of particular importance to student motivation, as most students believe that improving their English language speaking ability is the primary purpose of an oral communication class (Miles, 2009). In the past we have found that when students feel that the skills they are learning when they are doing their presentation will be useful in other situations, they will be more likely to spend time preparing and practicing for their presentation (Zivkovic, S : Journal of Educational and Social Research Vol. 4 No.4, June 2014). then he continues his discussion with Delivering a Spoken Presentation

\subsection{Prepare the Presentation Slide}

When the students paper as one presentaion tasks is finished and already checked then the next step is to prepare students with the slide. Students do it in group preparing the power points. Remind them that slide will also determine the success of the presentation.

\subsection{Rehearse The Presentation}

"Practice makes progress" wise word says'. Please remind the students to practice many times at home as kind of group work. Before the whole class presentation begun, we train a general hints for presentation then students start presentation in front of small groups consist of 4 to 6 students in chains. It means presenter from group 1 will stand up in group 2, presenter group 2 will be in group 3 and etc. Rehearse considered as way or techniques 
to reduce presenter anxiety. The small group presentation will be continued untill the last group. The next meeting the group presentation will really do the real whole class presentation. The first and the second presentation would be very hard, but the third till the last group would be easier. They already got the correction, input, suggestion from their class after the other group finished it. Why rehearse should be done several times ? Rehearse will help you to:

- become more familiar with what you want to say, so you feel secure and calm at the time of the presentation;

- identify weaknesses in your presentation;

- practise difficult pronunciations;

- check the time that your presentation takes and make any necessary modifications

\subsection{Delivering a Spoken Presentation}

During delivering the presentation we ask students students to pay full attention, because the topic of discussion is related with the subjects they will learn from other lecturers of other subjects in their majors.We ask students to be active listener and will be invited in questions session at the end of the presentation.

Since spoken presentations involve multi-skills, a carefully planned and constructed guideline will help develop students' receptiveness to these presentations. Listing instruction-al objectives and explaining reasons for this activity can increase student participation and may always result in a heightening of satisfaction and achievement. The fundamental purpose of scientific discourse is not the mere presentation of information and thought, but rather its actual communication (Gopen, 1990).

Students whose major Management Logistic will discuss topics such as : history of logistics, modern management of logistics, Principal of management, managerial skills, all topics related with the business of palm oil. While students from Processing technology will choose topics like : Harvesting of palm oil, opening the palm oil estate, the design of palm oil mills, prosses of palm oil 
from the estates to the mills, etc). The syllabus in that campus is absolutely new because Polythecnic of Palm oil is the only college specilizes in palm oil business. Books, references, sources about palm oil knowledge are still rare. The appendix will provide some topics or tittles of students presentation in their oral presentation task.

\subsection{Top Tips in Delivering Presentations}

We may not feel bored to remind the students with their language mistakes they use such us, mistypes, mistranslation,ungrammatical phrases or sentences in writing and spoken form of the task. Mispronunciations are often found during the presentation and they do it for many times. They make mistakes because there are many new vocabularies with area of English for Special Purposes. Dealing with these difficulties, the writer of the article * suggests some top tips to follow so that, they become a confident and compelling speaker. The 5 top 5 tips are:

\section{1) Don't read your slides}

Surveys have shown that presenters who read their slides are the number one most hated thing about Power Point presentations. Who wants to be hated?

\section{2) If possible, use a remote device for advancing your slides}

This allows you to move out from behind the computer and/or lecturn and enables you to connect to your audience. Most departments have them if you ask nicely!

3) Know your material and ditch the notes when you can so you connect better

\section{with your audience}

There is no quick fix for learning your material, you just have to get your head down and do it I'm afraid. Ideally, all you should need is a quick glance at the slide (or some cue cards) and you should know what you want to say to explain your point. Nervous and new presenters are clearly going to struggle with this - but don't panic, use your notes to begin with and eventually you will grow in confidence and be able to ditch them when you 
can. The worst case scenario is that you could take 3 years getting to this point - but at least you will be fabulous for your first job interview presentation!

\section{4) Rehearse, rehearse, rehearse}

Even experienced, professional speakers rehearse their narration. Personally I rehearse it at least 2-3 times sitting in front of the computer (timing it to make sure I'm not going to run over or be way too short). Saying it out loud is important and you may feel a bit self-conscious, but the computer is a very uncritical audience! If you are an inexperienced presenter and do not think you will be able to manage without reading from your notes, at least memorise and practice some short passages so that you can have some eye-contact with the audience and make them feel involved.

\section{5) Be yourself}

If you are a natural performer - go for it. If you are naturally reticent, keep it simple. The quote on the image here is from Sir Ken Robinson, a former government advisor on education who champions supporting creativity in children. He has given some of the most-watched presentations at the renowned TED conferences. He has a really simple presentation style with little or no visuals but manages to keep the audience hanging on his every word by making them feel he is just having a chat.

\subsection{The Procedure of Presentation}

The lecturer also train and drill students special expression that would be used in presentation. How to greet, introduce the group and the group member, the topic, and present the materials. The rule to be a moderator will be different with the role to be speaker or to be participants who ask questions or express disagreements. The lesson from this side teaches and recommends things such as : using notes, things to do and things not to do. The lessons are as follows:

\section{Notes:}


Consider using notes instead of relying on your memory. Rather than writing pages of paper, or using the overheads and slides as prompts, try to use record cards. On each card you might write one of your key ideas, followed by words to remind you of the example that you plan to use. Note cards are convenient and allow you to be more mobile during your talk.

Keep visual aids covered until you need to show them. Remove them when they have served their purpose. Remember, that when you are using visuals you should not turn your back to the audience. You may also want to reproduce your slides or acetates on your cards.

\subsection{Task}

Basically there are two types of task in speaking class of English I and II. Firstly, The Paper Task, secondly Presentation Task. The significant difference between English I and II is ; in English I is task group either paper or presentation, while in English II the task is individual, They will accomplish individual paper and presentation. Piles of paper stored in lecturers locker and we can't show it here just the tittle of the paper in appendix 2 and 3.

\section{Definition of Task}

What is a task? Jeon \& Hahn's (2005) survey of definitions reveals that tasks are:

(1) Goal-oriented, (2) Input-driven, (3) Procedure-Guided, (4) OutcomeEvaluated,

(5) Classroom-Setting, (6) Meaning-Focused, (7) Related to the real world.

(8) Involves learners in assuming a variety of roles, (9) Requires time for feedback,

For the purposes of this paper, it can be said that the major components of a task-based framework are: goals, input data, classroom setting, and assessment. For the teacher using oral presentations as a classroom task, pedagogical objectives can be as broad as developing learners' communicative competence through to more specific ones such as developing 
a five minute interactive oral presentation to be evaluated by peers. Naturally, goals should take into account learner needs and interests in order to stimulate motivation for using the target language.

According to Jeon \& Hahn (2005), verbal materials may be written or spoken language while non-verbal materials include various visual forms. In the context of oral presentations,verbal elements would include a written format for composing a simple speech and non-verbal material would be in the form of visual aids which learners organize into an A3 size poster. Again we can see that input data will directly reflect the learners' needs and interests and subsequently promote the use of the target language. In using oral presentations as a classroom activity, pair, small group and whole class modes are employed to encourage interactive language use. The final classroom setting on "Presentation Day", attempts to simulate the atmosphere of an interactive art gallery in which learners' posters are placed at regular intervals around the walls and individual audience members travel from poster to poster. The teacher is also free to move around the "gallery" while acting as facilitator of the activity. Thus it can be seen that a flexible arrangement of the classroom space will allow task participants and the teacher to experience different settings according to the particular learning situation.

\section{Methodology}

This study used in this paper is decriptive research method that describes and interprets the outline program of presentation task in English class in Palm Oil Polytechnic Citra Widya Edukasi, Bekasi practically and theoritically . The population is the first year students consists of six classes consist of three hundreds (300) students, with four classes as the sample of research consist of two hundreds students.

\section{B. RESULT AND DISCUSSION}

This study doesn't aim at proving the relationship and the effect of translation task on speaking skill, but it aims at aims at presenting the general outline of 
designing oral presentations task in speaking class. It also used descriptive methodoly in the analysing the design of English program in the first year of College, speaking class, oral presentation skills, paper of presentation, and oral presentation task in speaking class. The writer just noted and recorded the beginning score of speaking, on going progress of speaking, and final progress at the end of the semester. The scoring also purposes for very academic evaluation, that is completing the score of a subject in one semester like other subjects in college. The writer still has big intention to continue the reasearh using different research methodology to prove and to find out the relationship or effect of presentation task on speaking class, that is by using quantitative reasearch method.

In general the writer can conclude that presentation task is one of the effective techniques in teaching speaking class. The students's perception, the positive attitude, learning motivation of learning english are increased. Those all can be proved easily by observing the speaking class. In speaking class students are active to compete each other to take part and perform the speaking performance in front of the class. They never refuse to perform the speaking activity, and students attendance to the English class is almost $99 \%$ in one semester.

We score their level of speaking they have by individual and informal introduction at the very beginning of the class, the first speaking practice from module, daily speaking lesson from the module, on going speaking practice, presentation paper, ppt, the presentation rehearse, on going and daily presentation practice. The results show satisfactorily. It can be seen from the changing of the students aptitude and attitude toward English class. At the end of semeser there is a test or evaluation as a part of Final Term Test of English I. In English II the writer continues to do the same things like in English I such as speaking class, but the different is the task using the individual presentation task, not group presentation task anymore. 


\section{CONCLUSIONS AND SUGGESTIONS}

\section{Conclusion.}

Observing some journals of presentation and experiment done in classes it is true and proved that oral presentation is an effective way for improving and accelerating the speaking skills through some steps arranged in systematic syllabus especially for college students who have different discipline of knowledge or major in campus. Many activities done by students before presentation. Starting from choosing the topic, browsing the materials, reading and selecting materials to be paper task, preparing the power points, rehearsaling the task at home and in class. Presentation task also can be applied to all students in college with different majors. It is not only for college where the writer experience the experiments, but it also can be applied in any colleges and any majors with well prepared design of syllabus, consistant, and very deep hearted to succeed students speaking skill.

\section{Suggestions.}

There must be follow up research of presentation skill and presentation task with different methodology to prove the effectivenes realationship and effect of presentation toward the speaking skill. Some journals of presentation say so, that nowdays only few research of presentation done in college classes. It is very special invitation for other writers to complete this study for further research thoroughly. Since this paper also guides how to implement the presentation task completely in classess of university or college level, the writer suggest some lecturers in college to apply this for their classes, not only English but also all subjects. 


\section{BIBLIOGRAPHY}

Gopen, G. D., \& Swan J. A. (1990). The Science of Scientific Writing. American Scientist, Volume 78, 550-558.

Harmer, Jeremy. The Practice of English Language Teaching, 4th edition, Pearson Longman:USA, 2007

Halliday, M.K. Language as social semiotic. London: Edward Arnold, 1978

Hovane, M. Teaching presentation skills for communicative purposes. Kansai University Foreign Language Education Forum, 8, 35-49, 2009

Jeon, I.J., \& Hahn, J. Exploring EFL teachers' perceptions of task-based language teaching: A case study of Korean secondary school classroom practice.

Asian EFL Journal, 8(1), 123-143, 2006

King, J. Preparing EFL learners for oral presentations. Journal of Humanistic Studies, 4, 401-418. Retrieved August 20, 2012.

Mac Anthony, Diarmuid Gerardine and Mc Crohana. Pedagogical Justification for Teaching Presentation.

Murphy, H. A., \& Hildebrandt, H. W. Effective business communications. UK: McGraw-Hill Ryerson Limited, 1990

Reich, R. The work of nations: Preparing ourselves for 21st century capitalism. New York: Knopf, 1991

Sladana Živkovic, Journal : Teaching Students How to Master Spoken Presentation Skills, ISSN 2239-978X, ISSN 2240-0524, College of Applied Technical Sciences \& Faculty of Civil Engineering and Architecture, University of Niš, Serbia

Tarnopolskyy O. B., Avsiukevych Y. S. Successful Presentations. A Coursebook for Teaching Business Presentations in English. Kyiv: Lenvit, 2007

Tkachenko, V. Iryna. Teaching Presentation Skills To Students Of Business

English, Reader, Cherkasy Banking Institute of the University of Banking, NBU 